\title{
The Application of Information Technology in the Preparation and Presentation of Financial Statements: Nigeria in Perspective.
}

\author{
Nwosu M. Eze ${ }^{1}$ Mshelia M. Ibrahim ${ }^{2}$ \\ ${ }^{1}$ Internal Audit, National Institute for Legislative Studies, National Assembly, Abuja, Nigeria \\ ${ }^{2}$ Finance \& Accounts, National Institute for Legislative Studies, National Assembly, Abuja, Nigeria.
}

\begin{abstract}
Much of the activities in the preparation and presentation of financial statements are now driven by ICT. The enormous advantages (ICT) has accrued to the delivery of information and communication around the World, as well as the central role of ICT in the new global economy, means that ICT will indeed shape the dynamics of the new millennium. The role of and potential for ICTs in private and public sector accounting, auditing, investigation and reporting is enormous and cannot be over emphasized. This paper therefore assesses the types, benefits, challenges of using electronic accounting processing systems in the preparation and presentation of financial statements in Nigeria. The paper also highlights the Web based accounting system as well as the Peachtree accounting package; the Peachtree accounting package was practically illustrated and the results were presented in Spreadsheet. Secondary sources of data is mostly used. The paper concludes that the losers in this era of digital and information revolution will be organizations and professionals who fails to meet the challenges of Information and Communication Technology (ICT). Based on the findings and conclusion, the paper recommends that Accountants/Professionals should adequately equip themselves with the practical knowledge of information technology relevant in preparing and presenting financial statements.
\end{abstract}

Keywords: Information Technology, Electronic Accounting, Web-Based Accounting, Peachtree Accounting, Financial Statements, Public Sector Accounting.

\section{Introduction}

The information technology (computer) is a fast "developing one that keeps changing every now and then. It has touched every profession; thus changing our way of doing things in an organization and society as a whole. Of particular importance is the electronic accounting aspect which has brought about speedy, timely and efficient information processing which is very significant for day to day accounting and reporting as well as decision making.

E-accounting simply means using electronic processing computer base systems to:

- Acquire Financial Data

- Processing

- Storage

- Planning and Forecasting

- Coordination and Cost Control

- Dissemination of Vocal, Textual, Pictorial and Numerical Information for timely decision making.

\subsection{E-Accounting Applications Scope:}

As at today, most advance organizations are fast changing from their manual accounting system to electronic systems. Presently, the following accounting softwares are available in Nigeria to solve accounting and financial problems:

- Dac Easy for Window

- Ms-Money (Financial Management Software)

- Spec - Pay (Personnel Management Software)

- Eagle Tracks for Inventory Management

- MYOB Accounting

- Sages Accounting Software

- Peachtree Complete Accounting

- Budgetmatic Software for Budgeting and Budgetary Control

- Sun System Software

- Tally Accounting

- Fund Manager Etc. 


\subsection{Benefits of using E-Accounting in an Organization}

The following are the benefits of appropriate usage and application of electronic accounting in organization; especially Peachtree Accounting Software. You are able to:

- Get quicker Information on Financial Position of the Organization by just pressing/touching a button.

- Ascertain with Accuracy the Revenue Generated in an Organization on daily, weekly, monthly, quarterly etc. within a second.

- Provide detailed Expenditure Information to aid the Management in Cost Control and facilitate DecisionMaking.

- Budget and Forecast e. g. Annual Budget etc.

- Reduce Clerical and Administrative Overheads.

- Project Monitoring and Variance Analysis.

- Prevent Frauds.

- Eliminate Drudgery in Financial Planning.

- Get timely Report and Financial Statement after every Transaction.

- Audit Trail and Alarm for use as Security Proof to deter an unauthorized user.

\section{Web-Based Accounting}

A web-based accounting package is a complete accounting system that resides on a web server. Anybody in the world can access that accounting system with a simple browser to set up and run their own company. Instead of paying large sums of money up front for hardware and software, the user pays a smaller monthly rental fee. It is an interesting concept and there are many inherent benefits, some of which are listed below:

\subsection{Benefits of Web-Based Accounting:}

1. You Only Need a Browser: To use web-based accounting solutions, you need only a browser on any computer and a connection to the Internet. This makes it very easy to deploy the system throughout your organization. Remote users can even access the system through computers located at the airport or in a cyber cafe. It is the ultimate thin client model and virtually no effort or expense need be incurred to deliver access to everyone in your organization.

2. Lower Up-Front Costs for Software: Customers avoid paying larger upfront costs to purchase the software. Large fees for annual upgrades are avoided as well. Instead, the actual cost of the software is spread over time to achieve a better matching of expenditures to the benefits produced by those expenditures.

3. Lower Up-Front Costs for Hardware: Customers avoid paying larger upfront costs to purchase and implement a file server and network software. Ongoing costs to add RAM to the file server replace the server's hard drives; maintain the systems etc. are also avoided.

4. Lower Administration Costs: Customers avoid the need to hire an expensive IT professional staff or consultants to maintain the system. Typically systems that run on the higher-end Microsoft SQL server and Oracle databases require an IT professional on staff or on call. With the web-based model, certified engineers are on staff night and day to maintain your system, and their cost is included in the monthly rental fee.

5. Shorter Implementation Time Frame: The implementation time frame is significantly reduced because the system is already up and running. The customer needs only to log in and begin to enter data. The training requirement will remain the same whether the system is running locally or via the web.

6. Lower Costs for Multiple Locations: In the past, companies with multiple locations were forced to purchase expensive solutions such as Citrix or Microsoft Terminal Services Advanced Client to accommodate remote access to the accounting software database. These remote access solutions alone cost $\$ 15,000$ to $\$ 30,000$ and higher, which prices these solutions out of reach for many small businesses. With the web-based accounting model, even the smallest of companies can achieve data entry into a single system from multiple locations at affordable prices.

7. Work from Home: This solution is also ideal for small business owners who occasionally want to work from home. Suppose a child is sick and cannot attend school on a given day. Web-based solutions make it easier for the parent to stay home with the sick child, and still access the web-based accounting system to process payments, print reports, input transactions, etc. As another example, a web-based accounting system might make it easier for a working parent to leave the workplace early, for example at3:00pm, and continue working from home in order to miss the rush hour and to be there when the children gets home from school.

8. High-End Databases: These solutions run on the world's most robust and secure databases such as Oracle and Microsoft SQL server, yet these solutions cost as little as $\$ 10$ per user per month. One of the common shortcomings of low-end accounting systems has been that they incorporate weaker database technology that does not scalenearly as well as higher-end databases. Today, all web-based accounting solutions use the same 
high-end database that powers the largest companies in the world. In other words, small businesses need not worry about outgrowing the system's capacity.

9. No More Backup Worries: With web-based accounting solutions, backups are maintained on a frequent basis which further protects small businesses in the unlikely event of data loss. Studies show that only a small percentage of small businesses perform regular backups properly and store them off-site. With web-based accounting, the company can still maintain their own local backups if they want, even though the Web-based accounting publisher performs rigorous back up procedures religiously.

10. Up-to-date Application Code: Under this model, web-based accounting solutions apply enhancements and patches to their product on a continuous basis compared to the older method in which customers receive patches and enhancements once or twice a year. The result is that web-based solutions can be more responsive to the customer's needs and the application itself always reflects the latest version. There is no more need to pay consultants hefty fees to come in and implement system upgrades - this occurs automatically on a timely basis and with no additional cost to you.

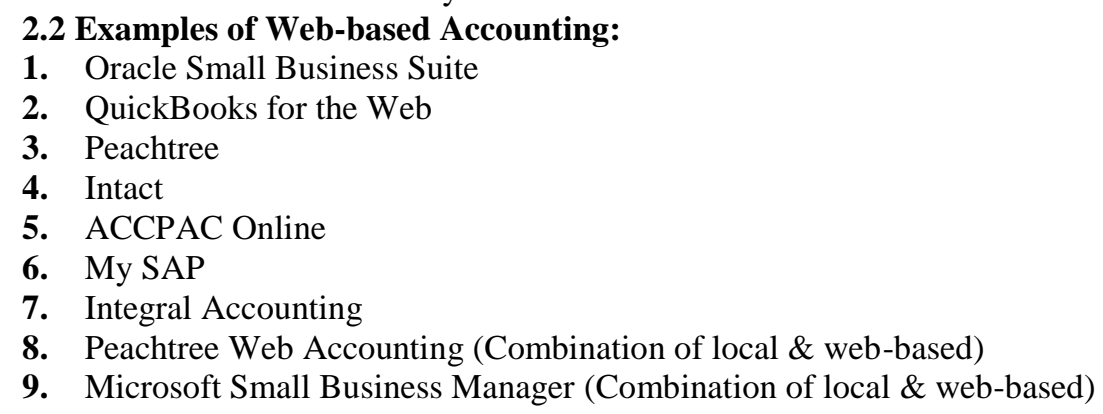

\subsection{Challenges of Web-Based Accounting:}

There are several problems with web-based accounting as follows:

1. Speed - Dial up access to the internet is not enough. It takes cable, DSL, or business class high-speed internet access to make web-based accounting work at acceptable levels of performance. If you have dial-up access, don't even bother. On April 3, 2002, Mark Cho of Intuit reported to me that Intuit does not even target small businesses with dial up access - they actually tell them that QuickBooks for the Web is not for them. This is a valid concern which is very easily solved - order high speed internet access today. I am usually a very polite person, but when it comes to this particular issue, I have to say that only an idiot would use dial up access anyway.

2. Reliability - Web-based accounting relies $100 \%$ on the internet being up and running and available. I can assure you, the internet is not always up and running and available. Ask yourself, how many times has your internet access been down this year? If the internet is down - you are down, and most likely your business is down as well. Ouch! This is a valid concern and there really is no answer other than employing a local/web solution such as Peachtree Web Accounting or Microsoft SBM.

3. Viruses - Because of rampant viruses and media attention, many people fear that they might be at a higher risk to contract a virus if they run their accounting system on a web- based system. There is little basis for this. Yes, viruses are a serious threat. You should be running virus protection software and a firewall device anyway. Theoretically, you are at the same risk level of contracting a virus whether your accounting system is on line or stored locally. The threat of viruses is not a very valid concern in my opinion.

4. Security - Most companies are very concerned about sending their data over the internet. They fear that their data will either be viewed or compromised. The reality is that with 128 bit encryption, sending you data over the internet is probably far safer than whatever you are currently doing now. If you currently keep your data on a file server at the office, the thieves could steal the computer, fire could destroy the computer, unauthorized employees might access the system, janitors or security guards may access to your system at night, backup tapes could be left in non-secure environments, etc. While nothing in this world is $100 \%$ safe, security experts agree that web-based accounting results in a more secure solution than most traditional file server based systems. Security is not a very valid concern in my opinion.

\section{Peach Tree Accounting}

This software comes in different flavors depending on the number of users. Between Peachtree Pro, Peachtree Complete, Peachtree Premium and Peachtree Quantum buyers can choose from among several features, depending on what they specifically require. Of these, Peachtree Premium and Peachtree Quantum also have Accountants 'Editions, which can prove to be of great use for professional accountants. Added to these are several accounting and business management tools, reports customized for industry specific needs, and even payroll management solutions - you have a complete accounting software package that is just right for your pocket as well. 
3.1 Reasons Why Most Organization Prefers Peachtree Accounting to Any other Accounting Package(s):

- Cost Effectiveness

- Comprehensiveness

- Reliability

- Flexibility

- Portability

- Interfacing

- Storage

- Timing

- Peripherals

- Documentation

3.2 Basic Steps in Using Peachtree Accounting

1. Set Up A New Company Tips/Procedures:

- Click Start button

- Click on program, select and click Peachtree Accounting

Note: Peachtree Window dialog box will display'

Click on set up a new company

Peachtree new company set up wizard/dialog appears. Click next

Type the Company information e.g. Company Names, Addresses, City, State etc.

\section{Click Next}

Select a chart of Account e.g. set up a new company on using Samples, Copy

Chart from existing Peachtree Accounting Company, etc.

Click next and select chart of accounts as related to your business line

- Select accounting method e. g. Accrual or cash and Click next

- $\quad$ Select posting method e. g. Real Time or Batch and Click Next

- Select Accounting period and click next

- Select the monthly accounting periods e.g. Jan-Dec 2010. The first month of Data entry e.g. J an. 2010, first year of entering payroll select 2010 and click next.

- Click finish.

2. Working With Chart Of Accounts Tips/Procedures:

Option 1: Set Up a New Chart of Accounts

- Click on "MAINTAIN MENU"

- Click on Chart of Accounts

A dialog box will appear:

- Type Account ID Number

- Type the Account description

- Select account type e.g. Cash, Income, and Expenses etc.

- Click save

Option 11: Modify Existing Chart of Accounts.

- Click on "MAINTAIN MENU"

- Click on Chart of Accounts

A dialog box will appear

- Click on Account ID and Select the account chart to be modified

- Type a new ID Number and description as necessary

- Click on save option

Option III: Delete chart of accounts

- Click on "MAINTAIN MENU"

- Click on Chart of Account

A dialog box will appear

- Click on Account ID and select the account chart to be deleted

- click on Delete option

A dialog box appears asking you "Are you sure you want to delete this record?"

- Click yes. 


\subsection{Illustration}

The following transactions were extracted from the books of Memzeen Group Limited; a Manufacturing Company for the Year 2015.

\begin{tabular}{|c|c|c|}
\hline & Codes & $\mathbf{N}$ \\
\hline Sale - Wholesale & 1001 & $8,790,00$ \\
\hline Sales - Retail & 1002 & 697,520 \\
\hline \multicolumn{3}{|l|}{ Cost of Goods Sold } \\
\hline Materials & 2001 & $(1,043,100)$ \\
\hline Labour & 2002 & $(405,000)$ \\
\hline Overhead-Depreciation & 2003 & $(219,300)$ \\
\hline Overhead - Transport & 2004 & $(128,640)$ \\
\hline Overhead - Other & 2005 & $(32,160)$ \\
\hline Change in Inventory & 2006 & $(60,250)$ \\
\hline Pension & 2007 & $(51,975)$ \\
\hline Loss on Obsolete and Damaged Inventory & 2008 & $(29,000)$ \\
\hline \multicolumn{3}{|l|}{ Selling Expenses } \\
\hline Advertising & 3001 & $(60,000)$ \\
\hline Wages, Salaries and Benefits & 3002 & $(65,700)$ \\
\hline Bad Debt & 3003 & $(23,068)$ \\
\hline Others & 3004 & $(13,500)$ \\
\hline \multicolumn{3}{|l|}{ General and Administrative Expenses } \\
\hline Wages, Salaries and Benefits & 4001 & $(321,300)$ \\
\hline Depreciation & 4002 & $(59,820)$ \\
\hline Pension & 4003 & $(51,975)$ \\
\hline Share-Based Remuneration & 4004 & $(22,023)$ \\
\hline Interest on Lease Liability & 4005 & $(14,825)$ \\
\hline Research and Development & 4006 & $(8,478)$ \\
\hline Other Expenses & 4007 & $(15,758)$ \\
\hline \multicolumn{3}{|c|}{$\begin{array}{l}\text { Other Operating, Investing and Financing Income } \\
\text { (Expense) }\end{array}$} \\
\hline Share of Profit of Associate A & 5001 & 23,760 \\
\hline Realized Gain on Cash Flow Hedge & 5002 & 3,996 \\
\hline Dividend Income & 5003 & 54,000 \\
\hline Share of Profit of Associate & 5004 & 7,500 \\
\hline Interest Incomes on Cash & 5005 & 8,619 \\
\hline Interest Expense & 5006 & $(111,352)$ \\
\hline Income Tax Expense & 5007 & $(333,625)$ \\
\hline \multicolumn{3}{|l|}{ Equity and Liabilities } \\
\hline Ordinary Shares & 6001 & $12,000,000$ \\
\hline Reserves & 6002 & - \\
\hline Profit and Loss & 6003 & - \\
\hline Loan & 7001 & $1,000,000$ \\
\hline \multicolumn{3}{|l|}{ Assets } \\
\hline Land and Building & 8001 & $5,000,000$ \\
\hline Machinery & 8002 & $3,000,000$ \\
\hline Furniture & 8003 & $1,500,000$ \\
\hline Debtors - Wholesale & 9001 & 40,000 \\
\hline First Bank Plc & 10000 & - \\
\hline
\end{tabular}

\section{Notes}

1. All payments and receipts were effected through cheques, except credit transaction.

2. N30,000 is to be transferred to Reserves

\section{Required}

a. Create the Company, Chart of Accounts and Post the transaction above via General Journal.

b. Prepare the following Company's Reports:

i. Income Statement.

ii. Statement of Financial Position.

iii. Cash Flow Statement.

\subsection{Solution}

(a) Memzeen Group Limited Account List Monday, February 13, 2015

\begin{tabular}{lllr} 
Account ID & Description & Type & Running Balance \\
\hline 10000 & First Bank Plc & Other Current Assets & $N 0.00$ \\
1001 & Sales-Wholesale & Income & $N 0.00$
\end{tabular}


The Application of Information Technology in the Preparation and Presentation of Financial

\begin{tabular}{|c|c|c|c|}
\hline 1002 & Sales - Retail & Income & $\# 0.00$ \\
\hline 2001 & Materials & Cost of Sales & $\$ 0.00$ \\
\hline 2002 & Labour & Cost of Sales & $\$ 0.00$ \\
\hline 2003 & Overhead-Depreciation & Cost of Sales & $\$ 0.00$ \\
\hline 2004 & Overhead-Transport & Cost of Sales & $\$ 0.00$ \\
\hline 2005 & Overhead-Others & Cost of Sales & $\$ 0.00$ \\
\hline 2006 & Change in Inventory & Cost of Sales & $\$ 0.00$ \\
\hline 2007 & Pension & Cost of Sales & $\$ 0.00$ \\
\hline 2008 & Loss on Obsolete Inventory & Expenses & $\$ 0.00$ \\
\hline 3001 & Advertising & Expenses & $\$ 0.00$ \\
\hline 3002 & Wages, Salaries and Benefits & Expenses & $\$ 0.00$ \\
\hline 3003 & Bad Debt & Expenses & $\$ 0.00$ \\
\hline 3004 & Other Expenses & Expenses & $\$ 0.00$ \\
\hline 4001 & Admin Salaries and Benefits & Expenses & $¥ 0.00$ \\
\hline 4002 & Depreciation - Admin & Expenses & $¥ 0.00$ \\
\hline 4003 & Pension-Admin & Expenses & $¥ 0.00$ \\
\hline 4004 & Share based Payment - Admin & Expenses & $¥ 0.00$ \\
\hline 4005 & Interest on Lease Liab-Admin & Expenses & $\$ 0.00$ \\
\hline 4006 & Research \& Dev. Admin & Expenses & $\$ 0.00$ \\
\hline 4007 & Other Expenses-Admin & Expenses & $¥ 0.00$ \\
\hline 5001 & Share of Profit - Associate & Income & $¥ 0.00$ \\
\hline 5002 & Gain on Cash Flow Hedge & Income & $¥ 0.00$ \\
\hline 5003 & Dividend Income & Income & $¥ 0.00$ \\
\hline 5004 & Share of Profit - Associate B & Income & $¥ 0.00$ \\
\hline 5005 & Interest Incomes on Cash & Income & $\$ 0.00$ \\
\hline 5006 & Interest Tax Expense & Expenses & $\$ 0.00$ \\
\hline 5007 & Income Tax Expense & Expenses & $\$ 0.00$ \\
\hline 6001 & Ordinary Shares & Equity-does not close & $\$ 0.00$ \\
\hline 6002 & Reserves & Equity-does not close & $\$ 0.00$ \\
\hline 6003 & Profit \& Loss & Equity-Retained Earning & $\$ 0.00$ \\
\hline 7001 & Loan & Long Term Liabilities & $\$ 0.00$ \\
\hline 8001 & Land and Building & Fixed Assets & $\$ 0.00$ \\
\hline 8002 & Machinery & Fixed Assets & $¥ 0.00$ \\
\hline 8003 & Furniture & Fixed Assets & $\$ 0.00$ \\
\hline 9001 & Debtors-Wholesale & Other Current Assets & $¥ 0.00$ \\
\hline
\end{tabular}

(b) Memzeen Group Limited General Ledger/Trial Balance as of February 29, 2015

\begin{tabular}{|l|l|l|l|}
\hline Account ID & Account Description & Debit Amt. & Credit Amt. \\
\hline 10000 & First Bank Plc & $9,325,734.00$ & \\
\hline 1001 & Sales Wholesale & & $8,830,000.00$ \\
\hline 1002 & Sales Retail & & $697,520.00$ \\
\hline 2001 & Materials & $1,043,100.00$ & \\
\hline 2002 & Labour & $405,000.00$ & \\
\hline 2003 & Overhead - Depreciation & $219,300.00$ & \\
\hline 2004 & Overhead - Transport & $128,640.00$ & \\
\hline 2005 & Overhead - Others & $32,160.00$ & \\
\hline 2006 & Change in Inventory & $29,000.00$ & \\
\hline 2007 & Pension & $51,975.00$ & \\
\hline 2008 & Loss on Obsolete Inventory & $29,000.00$ & \\
\hline 3001 & Advertising & $60,000.00$ & \\
\hline 3002 & Wages Salaries and Benefits & $56,700.00$ & \\
\hline 3003 & Bad Debt & $23,068.00$ & \\
\hline 3004 & Other Selling Expenses & $13,500.00$ & \\
\hline 4001 & Admin Salaries and Benefits & $321,300.00$ & \\
\hline 4002 & Depreciation - Admin & $59,820.00$ & \\
\hline 4003 & Pension-Admin & $51,975.00$ & \\
\hline 4004 & Share based Payment-Admin & $22,023.00$ & \\
\hline 4005 & Interest on Lease Liab-Admin & $14,825.00$ & \\
\hline 4006 & Research \& Dev. - Admin & $8,478.00$ & \\
\hline 4007 & Other Expenses - Admin & $15,758.00$ & \\
\hline 5001 & Share of Profit - Associate A & & \\
\hline & & & \\
\hline
\end{tabular}


The Application of Information Technology in the Preparation and Presentation of Financial

\begin{tabular}{|l|l|l|l|}
\hline 5002 & Gain on Cash Flow Hedge & & $3,996.00$ \\
\hline 5003 & Dividend Income & & $54,000.00$ \\
\hline 5004 & Share of Profit - Associate B & & $7,500.00$ \\
\hline 5005 & Interest Income on Cash & & $8,619.00$ \\
\hline 5006 & Interest Expenses & $111,352.00$ & \\
\hline 5007 & Income Tax Expenses & $333,625.00$ & \\
\hline 6001 & Ordinary Shares & & $12,000,000.00$ \\
\hline 6002 & Reserves & & $30,000.00$ \\
\hline 6003 & Profit \& Loss & $30,000.00$ & \\
\hline 8001 & Land and Building & $5,000,000.00$ & \\
\hline 8002 & Machinery & $2,780,700.00$ & \\
\hline 8003 & Furniture & $1,440,180.00$ & \\
\hline 9001 & Debtors-Wholesale & $\underline{16,932.00}$ & \\
\hline & Total: & $\underline{\mathbf{2 1 , 6 5 5 , 3 9 5 . 0 0}}$ & $\underline{\mathbf{2 1 , 6 5 5 , 3 9 5 . 0 0}}$ \\
\hline
\end{tabular}

(c) i Memzeen Group Limited Income Statement for the Two Months Ended February 29, 2015.

\begin{tabular}{|c|c|c|c|c|}
\hline Revenues & $\begin{array}{l}\text { Current Month } \\
\mathbf{N}\end{array}$ & & $\begin{array}{l}\text { Year to Date } \\
\mathbf{N}\end{array}$ & \\
\hline Sales-Wholesale & $8,830,000.00$ & 91.74 & $8,830,000.00$ & 91.74 \\
\hline Sales - Retail & $697,520.00$ & 7.25 & $697,520.00$ & 7.25 \\
\hline Share of Profit -Associate A & $23,760.00$ & 0.25 & $23,760.00$ & 0.25 \\
\hline Gain on Cash Flow Hedge & $3,996.00$ & 0.04 & $3,996.00$ & 0.04 \\
\hline Dividend Income & $54,000.00$ & 0.56 & $54,000.00$ & 0.56 \\
\hline Share of Profit -Associate B & $7,500.00$ & 0.08 & $7,500.00$ & 0.08 \\
\hline Interest Incomes on Cash & $8,619.00$ & 0.09 & $8,619.00$ & 0.09 \\
\hline Total Revenues & $9,625,395.00$ & 100.00 & $9,625,395.00$ & 100.00 \\
\hline \multicolumn{5}{|l|}{ Cost of Sales } \\
\hline Materials & $1,043,100.00$ & 10.84 & $1,043,100.00$ & 10.84 \\
\hline Labour & $405,000.00$ & 4.21 & $405,000.00$ & 4.21 \\
\hline Overhead-Depreciation & $219,300.00$ & 2.28 & $219,300.00$ & 2.28 \\
\hline Overhead-Transport & $128,640.00$ & 1.34 & $128,640.00$ & 1.34 \\
\hline Overhead-Others & $32,160.00$ & 0.33 & $32,160.00$ & 0.33 \\
\hline Change in Inventory & $60,250.00$ & 0.63 & $60,250.00$ & 0.63 \\
\hline Pension & $51,975.00$ & 0.54 & $51,975.00$ & 0.54 \\
\hline Loss on Obsolete Inventory & $29,000.00$ & 0.30 & $29,000.00$ & 0.30 \\
\hline Total Cost of Sales & $1,969,425.00$ & 20.46 & $1,969,425.00$ & 20.46 \\
\hline Gross Profit & $7,655970.00$ & 79.54 & $7,655970.00$ & 79.54 \\
\hline \multicolumn{5}{|l|}{ Expenses } \\
\hline Advertising & $60,00.00$ & 0.62 & $60,00.00$ & 0.62 \\
\hline Wages, Salaries and Benefits & $56,700.00$ & 0.59 & $56,700.00$ & 0.59 \\
\hline Bad Debt & $23,068.00$ & 0.24 & $23,068.00$ & 0.24 \\
\hline Other Selling Expenses & $13,500.00$ & 0.14 & $13,500.00$ & 0.14 \\
\hline Admin Salaries and Benefits & $321,300.00$ & 3.34 & $321,300.00$ & 3.34 \\
\hline Depreciation-Admin & $59,820.00$ & 0.62 & $59,820.00$ & 0.62 \\
\hline Pension-Admin & $51,975.00$ & 0.54 & $51,975.00$ & 0.54 \\
\hline Share based Payment-Admin & $22,023.00$ & 0.23 & $22,023.00$ & 0.23 \\
\hline Interest on Lease Liab-Adm. & $14,825.00$ & 0.15 & $14,825.00$ & 0.15 \\
\hline Research \& Dev-Admin & $8,478.00$ & 0.09 & $8,478.00$ & 0.09 \\
\hline Other Expenses-Admin & $15,758.00$ & 0.16 & $15,758.00$ & 0.16 \\
\hline Interest Expense & $111,352.00$ & 1.16 & $111,352.00$ & 1.16 \\
\hline Income Tax Expense & $333,625.00$ & 3.47 & $333,625.00$ & 3.47 \\
\hline Total Expenses & $1,092,424.00$ & 11.35 & $1,092,424.00$ & 11.35 \\
\hline Net Income & $6,563,546.00$ & 68.19 & $6,563,546.00$ & 68.19 \\
\hline
\end{tabular}

(c) ii Memzeen Group Limited Statement of Financial Position as at February, 29, 2015.

\begin{tabular}{|l|l|l|}
\hline Assets & & \\
\hline Current Assets & & \\
\hline First Bank Plc & $9,925,734.00$ & \\
\hline Debtors-Wholesale & $\underline{16,932.00}$ & \\
\hline Total Current Assets & & $\mathbf{9 , 3 4 2 , 6 6 6 . 0 0}$ \\
\hline Property and Equipment & & \\
\hline Land and Building & $5,000,000.00$ & \\
\hline Machinery & $2,780,700.00$ & \\
\hline Furniture & $\underline{1,440,180.00}$ & \\
\hline & & $9,220,880.00$ \\
\hline Total Property and Equipment & & $9,220,880.00$ \\
\hline Other Assets & & \\
\hline
\end{tabular}


The Application of Information Technology in the Preparation and Presentation of Financial

\begin{tabular}{|l|l|l|}
\hline Total Other Assets & & $\underline{0.00}$ \\
\hline Total Assets & & $\underline{\mathbf{1 8 , 5 6 3 , 5 4 6 . 0 0}}$ \\
\hline Liabilities And Capital & & \\
\hline Current Liabilities & & \\
\hline Total Current Liabilities & & $\mathbf{0 . 0 0}$ \\
\hline Long-Term Liabilities & & \\
\hline Total Liabilities & & $\underline{\mathbf{0 . 0 0}}$ \\
\hline Capital & $12,000,000.00$ & 0.00 \\
\hline Ordinary Shares & $30,000.00$ & \\
\hline Reserves & $(30,000.00)$ & \\
\hline Profit \& Loss & $6,563,546.00$ & \\
\hline Net Income & & $\mathbf{1 8 , 5 6 3 , 5 4 6 . 0 0}$ \\
\hline Total Capital & & $\underline{\mathbf{8 , 5 6 3 , 5 4 6 . 0 0}}$ \\
\hline Total Liabilities & & \\
\hline
\end{tabular}

(c) iii Memzeen Group Limited Statement of Cash Flow for the Two Months Ended February, 292015

\begin{tabular}{|l|l|l|}
\hline & $\begin{array}{l}\text { Current Month } \\
\mathbf{N}\end{array}$ & $\begin{array}{l}\text { Year to Date } \\
\mathbf{N}\end{array}$ \\
\hline Cash Flows from Operation Activities & $6,563,546.00$ & $6,563,546.00$ \\
\hline Net Income & $6,563,546.00$ & $6,563,546.00$ \\
\hline Adjustments to Reconcile Net & & \\
\hline Income to Net Cash provided & & \\
\hline by Operating Activities & $(9,325,734.00)$ & $(9,325,734.00)$ \\
\hline First Bank Plc & $\underline{(16,932.00}$ & $\underline{(16,932.00)}$ \\
\hline Total Adjustments & $\underline{\mathbf{9 , 3 4 2 , 6 6 6 . 0 0})}$ & $\underline{\mathbf{9 , 3 4 2 , 6 6 6 . 0 0}}$ \\
\hline Net Cash provided by Operations & $\underline{\mathbf{( 2 , 7 7 9 , 1 2 0 . 0 0 )}}$ & $\underline{\mathbf{( 2 , 7 7 9 , 1 2 0 . 0 0}}$ \\
\hline Cash Flows from Investing Activities & & \\
\hline Used for & & $(5,000,000.00)$ \\
\hline Land and Building & $(5,000,000.00)$ & $(3,000,000.00)$ \\
\hline Machinery & $(3,000,000.00)$ & $\underline{(1,500,000.00)}$ \\
\hline Furniture & $\underline{(1,500,000.00)}$ & $\mathbf{( 9 , 5 0 0 , 0 0 0 . 0 0 )}$ \\
\hline Net Cash used in Investing & $\mathbf{( 9 , 5 0 0 , 0 0 0 . 0 0 )}$ & \\
\hline Cash flows from Financials Activities & & $12,000,000.00$ \\
\hline Proceeds From & & $30,000.00$ \\
\hline Ordinary Shares & $12,000,000.00$ & \\
\hline Reserves & $30,000.00$ & $12,030,000.00$ \\
\hline Used For & & $(249,120.00$ \\
\hline Net Cash Used in Financing & $12,030,000.00$ & \\
\hline Net Increase <Decrease> in Cash & $(249,120.00$ & 0.00 \\
\hline Summary & & $\underline{0.00}$ \\
\hline Cash Balance at End of Period & 0.00 & 0.00 \\
\hline Cash Balance at Beg of Period & $\underline{0.00}$ & \\
\hline Net Increase <Decrease> in Cash & 0.00 & \\
\hline & & \\
\hline & & \\
\hline
\end{tabular}

\section{Conclusion}

The world is undergoing revolution in information and communication technology (ICT), which is righty referred to as the digital revolution. The revolution is already transforming social and economic life and is moving at near lighting speed. Information and communication technology is one of the most potent forces shaping the $21^{\text {st }}$ century. It is fast becoming a vital engine of growth for the world's economy, creating opportunities for many enterprising individual, firms and communities, globally. The ongoing revolution in the area of information and communication technology will continuously present huge opportunities to internationally recognized scholars and professionals. The losers will be nations, institutions and scholars who fail to meet the challenges of ICT.

\section{Recommendations}

Electronic accounting and reporting is here to stay. So far, results have been fair to dismal. Becoming an accountant on a technology platform is a sure Way for accountants to secure their careers in the digital age. To remain relevant in the ongoing waves in accounting information technology, accountants require practical training in IT based accounting system. 


\section{Reference}

[1]. Adejola, P. A., (2012) Electronic Accounting and Reporting: An Information Technology (IT) Empowerment Tool for Professional Accountants, "Rainbow Prints, Abuja- Nigeria.

[2]. Adejola, P. A. (2010) Application of Information and Communications Technology. A Practical Approach, Rainbow Prints, AbujaNigeria.

[3]. Adejola, P. A. (2008) Data Processing and Management Information Systems: A Simplified Approach to Application of Computer, Rainbow Prints, Abuja- Nigeria.

[4]. Adegbeyeni, E. 0.Ezeiruaku, A. O. and Ajugu, E. G. (2001) Essential Computer Studies for Junior Secondary Schools, Longman Nigeria Plc.

[5]. Adekunle, O. E., Oduronke, T. E. and Olufunmilayo, M. A. (2002) Computer Studies for Beginners I, 2 Editions. Bounty Press Limited, Ibadan. Nigeria.

[6]. Bello, H.M. (2003) "The Role of Information and Communication Technology in the Fight against Poverty-the Nigerian Experience." (Paper Presented at the Symposium on ICT and the Society of Information. $9^{\text {th }}-11^{\text {th }}$ December 2002.Algiers. [online].Available at: http://alafrica.com/stories/200301200386.html.Accessed July, 2016

[7]. Bjork B. (1999) Information Technology in Construction: Domain: Definition and Research Issues: International Journal of Computer Integrated Design and Construction, SETO, London, May 1999, Vol. 1, No.1, Pp.3-16.

[8]. Brown, M.M. (2000) "Public Sector Information Resources in the coming Millennium: A Management Imperative," in Public Administration and Management: An Interactive Journal 5 (1) University of North Carolina.

[9]. Chan, S.C. (2002) "Information Technology in Business," Process Management Journal, 2002, Vol. 6, No. 3, P. $224-237$.

[10]. Chaharbaghi, K and Willis; K. (2000) The Technology Mythology and Economy of Technology, Management Decision, volume 38, issues 7.

[11]. Encyclopedia of Business Information (2001). “Information Technology,"

[12]. Frenzel C.W. (1999), Management of Information Technology, New York: Boyd \&Fraser Pub. Co.

[13]. Gates B. (1995), Business @ the Speed of Thought: Succeeding in the Digital Economy. New York: Warner Books.

[14]. Marchionini, G. (1997), Information Seeking in Electronic Environments: Cambridge University Press.

[15]. Marghalani M. A. (1987) Factors Affecting Information Technology Transfer in Developing Countries. Libris Vol. 37, Pp. 239-245.

[16]. Moll, P. (1983) “Should the Third World have Information Technologies?” IFCA Journal 9(4).

[17]. Nwosu M. Eze (2013) Principles of Accounting with Questions and Suggested Solutions. Petra Digital Press, Abuja- Nigeria ISBN 978-978-932-706-5

[18]. Nwosu M. Eze et al (2015) Information and Communication Technology Applications in Small and Medium Scale Enterprises (SMEs) Funding in Nigeria: An Impact Assessment-International Journal of Finance and Accounting. Vol. 4(5): pp.293-303. DOI:10.5923/j.ijfa.20150405.07

[19]. Odudimu, O. O. and Ajao, D. G. (2004) Essential Computer Studies for Junior Secondary Schools, Tonad Publishers Limited, Lagos, Nigeria. www.0ffice.com: Microsoft Case Studies Search 